\title{
Colonial and Counter-Colonial Design Methodologies: The Instrumentalization of Grids in the Public Interest
}

\author{
TIMOTHY J. APPLEBEE \\ University of Hartford
}

\author{
THEODORE R. SAWRUK \\ University of Hartford
}

In 2016 the Canadian landscape architect, Pierre Bélanger, unveiled "Extraction," a site-specific intervention at the Venice Architecture Biennale. Bélanger's installation drew attention to the grid as it was used by the British Empire to assert sovereignty over the full expanse of British North America (Canada) by implementing the Dominion Land Survey (1871-1930). For Bélanger's "Extraction," this sovereign act, specifically the act of placing a surveyor's monument to demarcate dominion, became a means to highlight $\mathbf{8 0 0}$ years of geological and human exploitation by the Crown. When used as a means of spatial organization, the grid supported the imposition of political and economic agendas by Colonial Europeans on the indigenous landscape and its inhabitants. Theories of architectural and spatial design methodology (per Manfredo Tafuri and Rosalind Krauss) contextualize the instrumentality of grids in our review of recent urban, architectural, and geo-spatial works by Pierre Bélanger, Alessandro Rosaneli, Jennifer Bauer and Kelly Rose. The paper concludes with an appraisal of the advance of geo-spatial grid mapping and its countervalent potential for design professionals.

Among all the arts - those children of pleasure and necessity in which man has participated to help him bear the trials of life and pass on his memory to future generations - one cannot deny that architecture must hold a most eminent place. Even considered only from the point of usefulness, it surpasses all the other arts. It ensures to the salubrity of cities, guards the health of men, protects their properties, and works only for the safety, repose and orderliness of civic life.

—Quatremère de Quincy (1832)

\section{INTRODUCTION}

Even if the colonial empires of the eighteenth and nineteenth centuries did not last, the physical, cultural, economic, and political legacies of colonialism continue to impact postcolonial civilization and its control of global resources. More specifically, the abject territorialism and architectural efforts materialized by these empires provided (and remain) the form of Western spatial politics and built environments. In the settlement of the new world and the creation of its cities, architects, engineers, and planners contributed to this consumptive and exploitative capital development practice based upon territorial domination, resource exploitation, and ethnic destruction. The ethical work of such professionals now operating within a post-colonial system requires a continual assessment of vestigial oppressions along with an assessment of the means and methods available to alleviate them.

This inquiry takes the position that those invested in contemporary spatial design - geographers, engineers, architects, and urbanists - become de facto arbiters of equality and social justice capable of acting as embedded operatives in the confrontation of systemic oppression. To describe how design professionals might envision and propose such meaningful change, the following research examines theories of architectural and spatial design methodology. The theoretical writings of Rosalind Krauss (Grids, 1979) and Manfredo Tafuri (Toward a Critique of Architectural Ideology, 1969) are examined for precedent methods and critical tools of spatial design.

Krauss's conception of grids emerges as formally instrumental, more so than Tafuri's ideological lineages. Kraussian grids, aesthetic and abstract, material and immaterial, are the tools of construct shared by artists, architects, planners, developers, and previous colonial empires alike. Given this formal paradigm and tool of design, we examine Alessandro Rosaneli's 2014 Grid Plan: New Towns in the Brazilian Coffee Frontier, followed by Pierre Bélanger's Venice Biennale 2016 exhibition and catalog, including his Manifesto for the Next Century (properly titled as Undermining Empire) printed inside the catalog dust jacket.

These constructive and critical uses of the grid in colonial and counter-colonial design provide the basis for a methodological consideration of the 2015 white paper authored by Jennifer Bauer and Kelly Rose, under the auspices of the U.S. National Energy Technology Laboratory. Their work, Variable Grid Method: An Intuitive Approach for Simultaneously Quantifying and Visualizing Spatial Data and Uncertainty, describes the advancements, opportunities, and limitations of the grid in contemporary spatial data mapping, analysis, and visualization.

In review of the research and artifacts provided by these authors, we conclude with an affirmative assessment of the positions presented by Krauss and Bélanger supported by the work of Rosaneli, Bauer, and Rose. The grid, equally abstract and concrete, virtually unbiased and yet laden with 
the legacies of colonialism, can and should be used by design professionals acting in the post-colonial public interest.

\section{PRECEDENT THEORY OF DESIGN METHODOLOGY}

This research approaches the ethics of spatial design from the perspective of architectural design methodology. To situate the ideologies and practices of contemporary designers, theorists identify and examine the chronologies of the cultural evolutions of such design practices. Specifically, how has the work and subject of design changed throughout a selected history, and what is the relationship between design and the self-critical process of the designer? Further, how do these historical assessments of design methodologies inform the contemporary practice of architects, planners, and artists?

Rosalind Krauss, in her seminal article, "Grids," examines the modern ideological lineage of "the arts of vision and those of language" over the course of the $20^{\text {th }}$ century, in particular the concept of the grid and its role in "modern aesthetic production." She draws upon the abstract works of modernist artists to understand the implications of the grid and exemplify her position. Even if "the bottom line of the grid is a naked and determined materialism," she recognizes that the painters "Mondrian and Malevich are not discussing canvas or pigment or graphite or any other form of matter. They are talking about Being, Mind, or Spirit. From their point of view, the grid is a staircase to the Universal, and they are not interested in what happens below in the Concrete." So the aesthetic of the grid (and more pertinent to this discussion of design methodology: the artistic/architectural instrumentalization of the grid) can be understood in her examination as a fulcrum between the material and the immaterial world.

The grid, as Krauss has described it, resonates with Tafuri's multi-faceted reading of Laugier's Enlightenment philosophy of the design of a park in the city, and even of the design of the city itself. Laugier, in Tafuri's view, describes an equally chaotic, circumstantial process and an analytical proposition, an unmindful destruction of personal histories paradoxically suffused with them nonetheless. For Tafuri, Laugier's urban park of the European Enlightenment, like any city structure, is a form within a form; a contextualized opportunity; a pragmatic and humanist design in confrontation of our own inorganic, controlling human tendencies; a confrontation (or exercise, more politely) of capital development practices from within. Similarly, the grid is at once a powerful instrument of creation for Krauss (1979), a "structure... that allows a contradiction between the values of science and those of spiritualism to maintain themselves within the consciousness of modernism," and a repressive, characterless, "schizophrenic' force in our aesthetic culture.

So the grid - abstract and operational, not reliant upon materiality, visibly resistant to any one narrative or discourse - provides artists, scientists, politicians a powerful point of pivot between the materiality of the body and the narratives of the mind, between an idea and its reality. For Krauss, however, the prevalence of grids in contemporary art practice belied the relatively infertile ground that the concept provided to the modern visual arts movement. The historically fruitful relationship between the grid and art production methodologies increasingly frustrated artists (and their audiences), she notes, stifling the creation of a meaningful aesthetic rather than providing unfailing inspiration.

If such critical knowledge is what students and practitioners should integrate into their work, we must then examine the relationship between capital development ideologies [and gridding] and those who work in their employ. How are these ideologies made manifest in the continual deployment of the urban planning and gridiron typology, as exemplified by the development of the Brazilian coffee frontier? In turn, how do alternative, dislocated, disempowering grids, such as the 2016 Canada pavilion in Venice, subvert them? And finally, how are various ideologies supported or threatened by governmental advancements in the use of grids for spatial data analysis, as in the use of a variable grid visualization method?

\section{THE BRAZILIAN FRONTIER OF GRIDS}

The grid, and to study grids, Rosaneli argues, 'becomes an intriguing exercise of the exploration of human inventiveness and its capability for unlimited composition on a single subject and, above all, how to assign and reveal different meanings in relation to the built environment." Rosaneli, a professor at the Federal University of Paraná (Architecture and Urban Planning) in southern Brazil, has examined the planning of early twentieth century towns in Paraná region of Brazil. His research, without acknowledging his academic position as an instrument of the state, "explores the creative use of the grid in almost 100 new towns in the last Brazilian coffee frontier." Before he delves into the pragmatic and fevered capital development of these gridiron towns by private real estate companies (most of them in the decade following the Second World War), he establishes the history and critical theory surrounding the urban grid.

Urban grids, despite formal similarities, are not all the same. They are sited in a variety of geographies and historical moments in the service of differing socio-economic motivations. Referencing a 2001 article by J. Grant, "The Dark Side of the Grid: Power and Urban Design," Rosaneli writes that the various forms of the urban grid - its street standards, lot and block sizes, and historical moment of inception, all contribute to classification of the urban grid as 'egalitarian' or 'hierarchical.' For Krauss, he adds, grids represent both centrifugal and centripetal existence and similarly for Marcuse, urban grids can be classified as an 'open grid' or 'closed grid.' A grid inserted within geographical or political limitations is closed, "whereas the open grid is laid out with a view towards expansion and reduplication, in one or more directions, without a boundary... 
serving as an initial step towards plotting an unknown and perhaps unlimited area capable of indefinite expansion." In either case, Rosaneli notes that Grant and Marcuse rest their typological descriptions on the socio-economic structures and spatial geographies of the societies they studied.

Despite his undisguised optimism and appreciation for the grid as a formal planning methodology, Rosaneli understands, citing the work of Kostof, that "the political innocence of the grid in the West is a fiction... The fact is that egalitarianism is no more natural to gridded patterns than to any other urban forms." Rosaneli's stance underscores the ambivalent nature of the grid as found in the Kraussian analysis, as well as in the warning issued by Marcuse that Rosaneli highlights: "the grid itself is neither 'good' nor 'bad' city planning: its effects will necessarily always be contingent on conditions of time, space, power and stage of economic development." Setting aside conflicts between affirmative and critical value judgments of the urban grid, the sheer utility of grid planning, as it is easily "settled in the field and documentarily transferred, even in times of limited technical knowledge and trained personnel," explains its continual adoption, and Rosaneli's own optimism for its future applications. The faults observed in gridded cities, Rosaneli concludes, are not those of the grid itself but of the planner.

According to Rosaneli, four factors converged in the early nineteenth century to inspire rampant gridded land
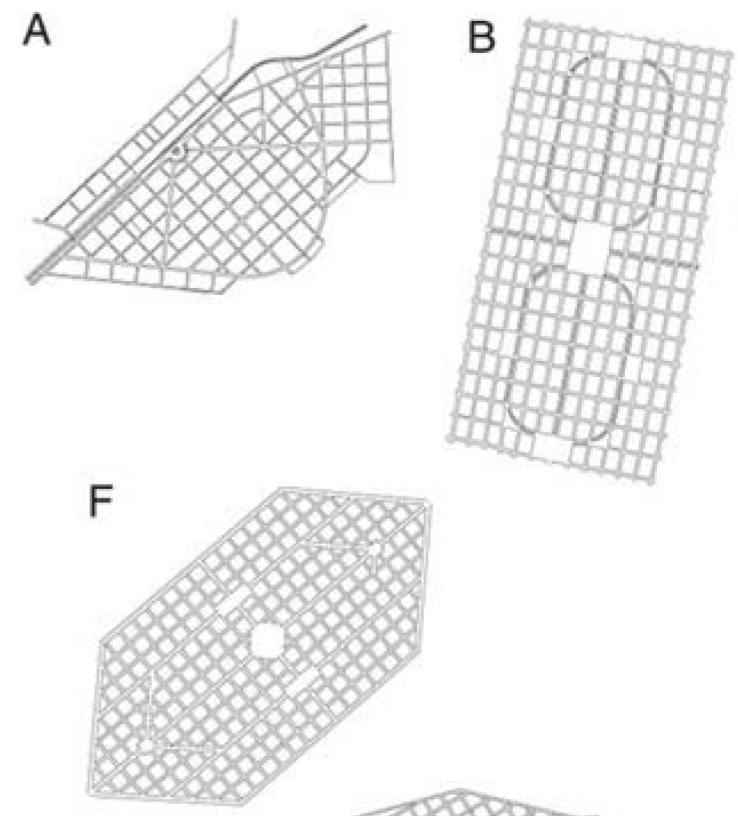

$\mathrm{F}$

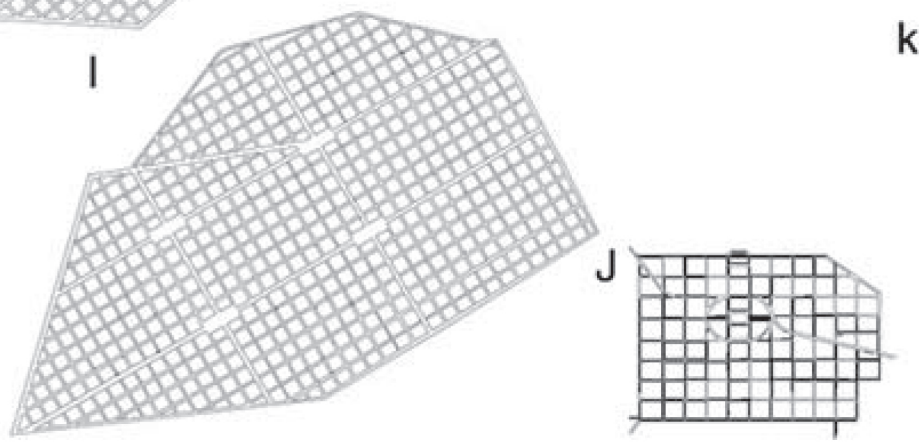

D
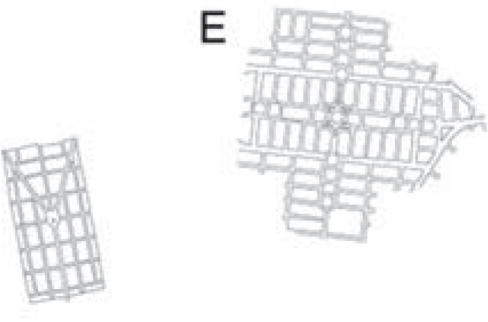

$\mathrm{H}$

G

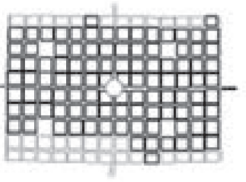

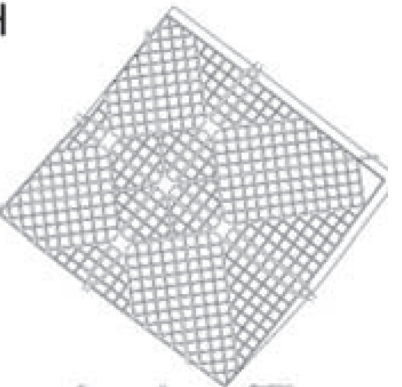

$\mathrm{k}$

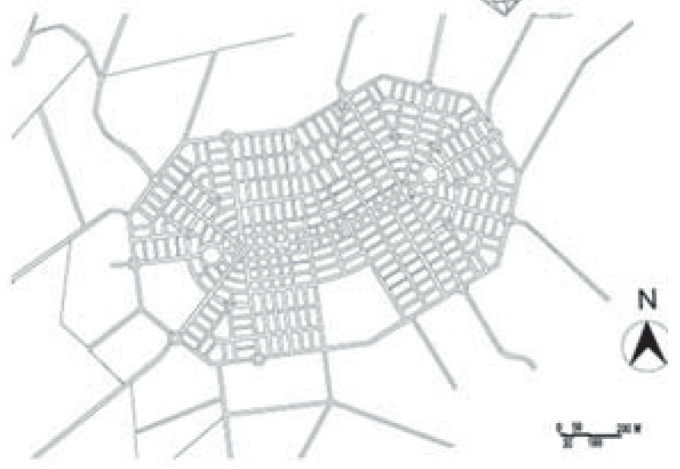

Drawings of the original plans: (A) Rolândia Town, (B) Querência do Norte Town, (C) Ivaté Town, (D) Lobato Town, (E) Tupãssi Town, (F) Cidade Gaúcha Town, (G) Itaúna do Sul Town, (H) Loanda Town, (I) Alto Paraná Town, (J) Londrina Town and (K) Pérola Town. Source: Rosaneli (2013); drawing by Isadora Ohata and Scharlise Minte. 
speculation: the entrepreneurship of private companies, the supportive governmental initiatives, the favorable global socioeconomic conditions following World War II, and the large, urban scale needed to process coffee. These factors all combined to make Paraná "responsible for nearly one-third of the world's coffee production" as coffee became Brazil's prized export. The adoption of the grid in this planning was shared by 40 different private real estate companies of various nationalities, a phenomenological capital development strategy, not an explicitly authoritarian exercise.

Rosaneli notes that most new town settlements, all designed by engineers, occurred along high ground between river ways, were typically rectilinear in their boundaries, utilized simple hierarchies of broad avenues and streets and plazas at important intersections, and (despite various formal nuances and dissimilarities amongst them) did not contribute any "spatial innovation" (see Figure 1). The roughly square blocks (up to 125 meters per side) found in earlier town plans were replaced by "economically advantageous" rectangular blocks $(150 \mathrm{~m} \times 80 \mathrm{~m})$ in the later town plans. The typical plot, regardless of town, was 15 meters wide by 30 or $\mathbf{4 0}$ meters deep. "Above all, this plot standardization was favorable for business decisions and legal registration" as the territory underwent rapid and uncertain transformations. Rosaneli concludes that while "uninspired" grid plans "impose a permanent speculative spirit on the territory," the open grid development of the Paraná coffee frontier yielded distinctive urban centers and offers a valid morphology for future urban grid design.

\section{EXTRACTION - A COUNTER-COLONIAL SPATIAL DESIGN STRATEGY}

Pierre Bélanger, a Canadian landscape architect by training and now Associate Professor of Landscape Architecture, Co-Director of the Master in Design Studies (MDes) Program in Urbanism, Landscape, and Ecology at the Harvard University Graduate School of Design, similarly researched the history of capital development and colonization in his home country, reaching conclusions that are far more critical. He also offers a prescriptive method of design for architects and landscape architects in the face of continued global resource exploitation by both public and private sectors of the international economy. His 2016 Canadian Exhibition at the Venice Architecture Biennale, with its catalog and related manifesto, demonstrate as much. In his manifesto, "Undermining Empire," he writes:

7. On the Planning Paradox: Resistance to industrialization is hard, negotiation is complicated. Institutional infiltration and systemic unplanning are tenuous and often contradictory proposals, but eventually they will become necessary strategies. Like a Trojan horse, the role of the counter-planner is to identify and fuel the emergence of counter-economies within new political ecologies.

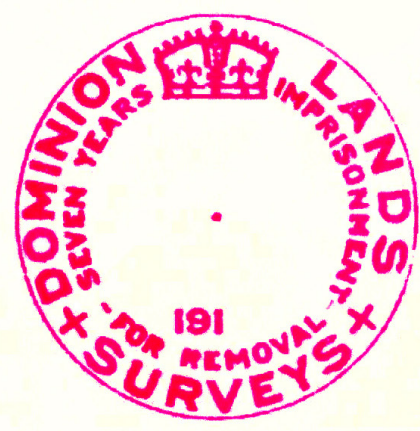

$\infty$

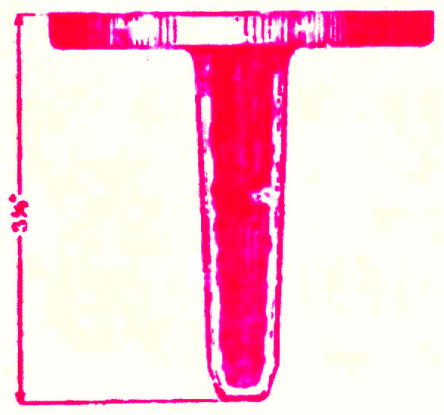

Monument

Benchmark for the Dominion Land Survey initiated after Confederation by the Government of Canada for land settlement 1869

Figure 2. Precedent survey monument for the Dominion Land Survey (Pierre Bélanger. In Extraction. Venice: Venice Biennale. 2016, 78.)

The exhibition itself, unlike the development of the Paraná coffee frontier, was not supported or condoned by the Canadian government. Upon learning of his proposal to infill Canada's exhibition hall with gold ore extracted by Canadian international enterprises, Bélanger lost fundraising and commissioning support and the hall was "closed for renovation" during the Biennale.

For Bélanger, the gridded, fully surveyed form of the Canadian federation (for the express purpose of political control and resource extraction), is Canada's historical strength and its moment of weakness as a political power. Bélanger here recognizes a monstrously ironic truth that $90 \%$ of the land on which Canada sits is Crown Land, originally established in 1763 by the Royal Proclamation of King George. This geological survey defines Canada's political and economic resources for capital development, while simultaneously conceding Canada's authority to the royal monarch of Britain (Figure 2).

The irony deepens under Bélanger's recognition that the aggregate of Canadian mining companies is the single most dominant force in global mining equity transactions. Referencing an 1898 postage stamp proclamation, "We Hold a Vaster Empire Than Has Been," Bélanger minces no words in describing Canada as "Britain's Bitch." 


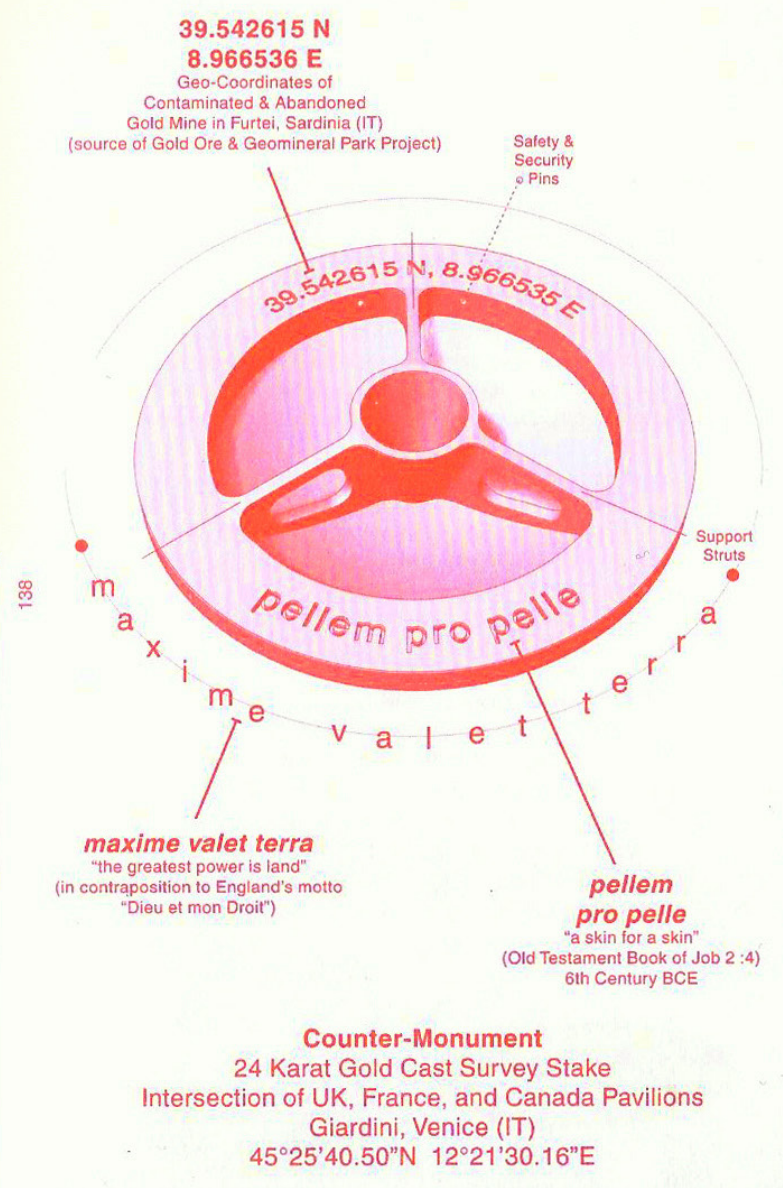

Figure 3. Bélanger's counter-monument (Drawings by OPSYS / Pierre Bélanger, Zannah Matson. In Extraction. Venice: Venice Biennale. 2016, pp. 138-139)

Deploying a Kraussian conception of the grid in resistance to his government, Bélanger's Biennale installation utilizes the physical crux of the gridded survey, the surveyor's monument (a stake placed in the land at every intersection of grid and property lines), and offers the global citizen a "counter-monument" installed in the Venetian plaza at the axial intersection of British, French, and Canadian Pavilions. Analyses of the urban grid and the territories it demarcates, as noted earlier, often focuses on its form or content, the physical and cultural trappings bound by the measured limits of the grid. Bélanger's counter-colonial stake in the ground, however, is focused on the defining moment of intersection.

Bélanger's counter-monument not only operates outside of the representative pavilions of colonial territories, it is a functional peephole that critically exposes 800 years of the Crown's empire building which he dates to the Magna Carta. (See Figure 3.) Attendees, distinguished and common alike, could kneel in the middle of the public plaza, bringing their eye even further down to the counter-monument installed

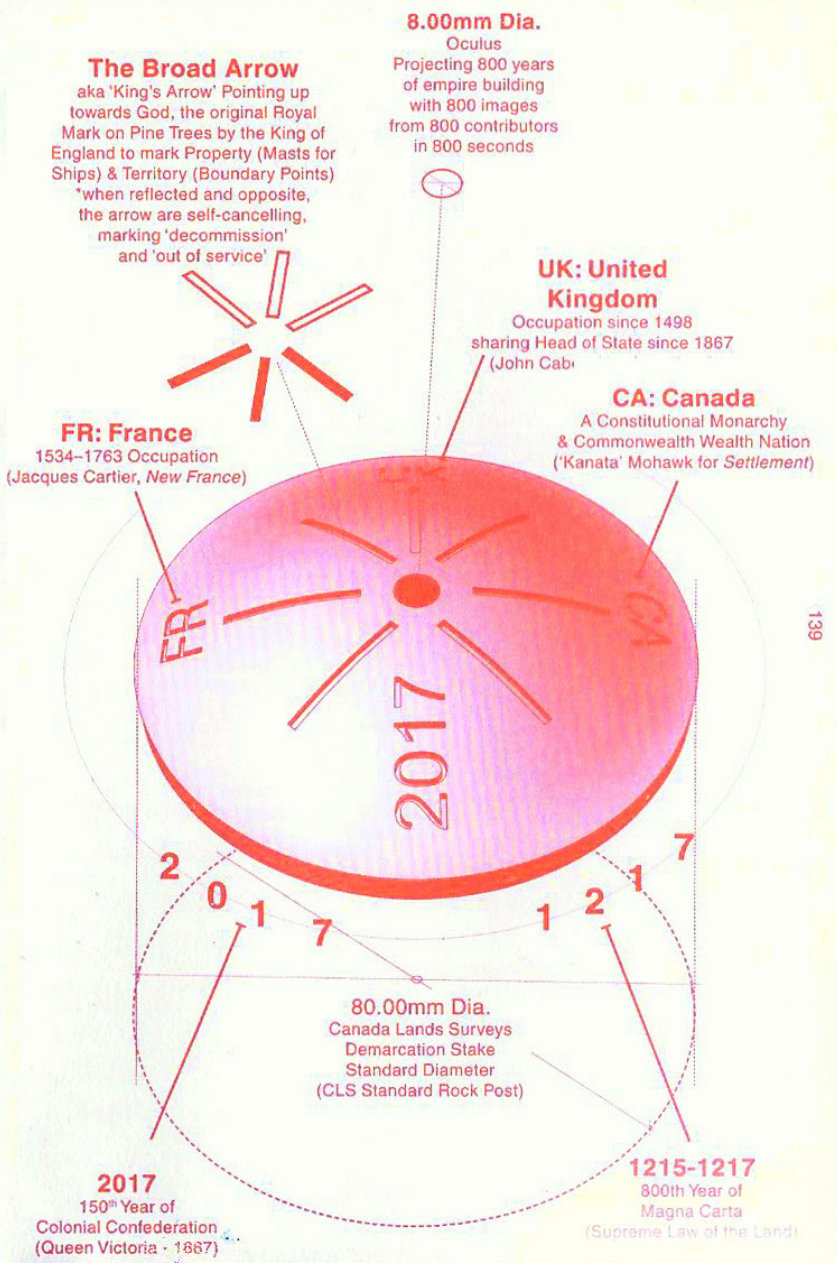

at finished grade, and view (through an $8.00 \mathrm{~mm}$ oculus cast into it) 800 images from 800 contributors curated over 800 seconds depicting the geological and human exploitations waged by the British and Canadian Empires over the course of 800 years. With visceral imagery and searing analytics, Bélanger effectively turned the intersection of global and local territories into an historical examination of our current place and role as colonizers, invaders, slave-owners, miners, rapists, and murderers in the name of capital development.

"Architecture now accepted the task of politicizing its own handiwork," Tafuri writes, "As agents of politics; architects had to take up the challenge of continuously inventing advanced solutions at the most generally applicable levels." Again, what is the system, what is the process, what is the recipe of a form-maker's ethically comprehensive effort? To where and to whom do ethically oriented counter-political artists, architects, and revolutionaries turn? For the contemporary counter-colonialist in search of a potent, transformative design methodology, it is paradoxically the grid, the considered, skeptical, well-researched application of the grid in plan, in section, and in virtual space and time, that should be regarded as the promising, dislocating antidote. 

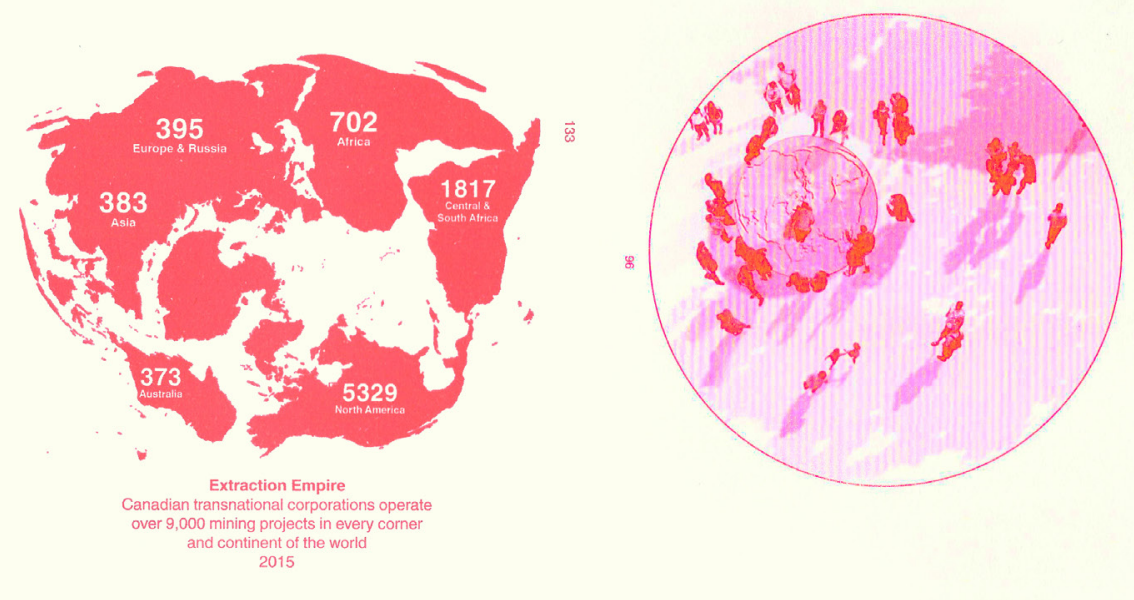

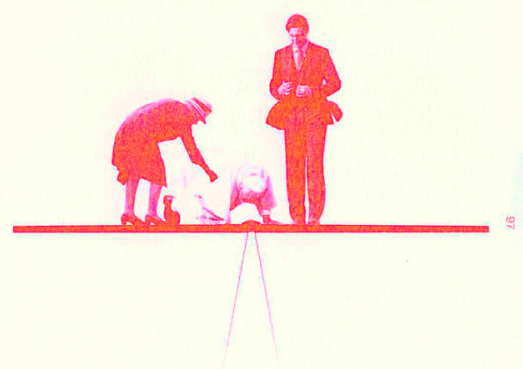

\#草 NoMore
Figure 4. Plan and section propositional drawings Canadian Exhibition (Drawings by OPSYS / Pierre Bélanger, Zannah Matson. In Extraction. Venice: Venice Biennale. 2016, pp 96,97, 133.)

The most powerful visualizations of Bélanger's countercolonial ideas are the plan and section proposition drawings (Fig. 5) of his Venice exhibition. In his section drawing, the Pope is kneeling, as if in a most humble prayer, in order to see through the oculus that the monument provides to all the public. In so doing, the Pope bears witness to 800 years of colonial design methods (depicted in Fig. 4). The Queen of England, bends to him on his right and the Prime Minister of Canada, a relative youth, stands to his left. Bélanger, operating with the fearlessness of a Canadian landscape architect, implicates the errors, abuse, and responsibilities that all three leaders represent, and proposes the land of Canada no longer belongs to the Crown.

In his plan drawing a random citizen is kneeling as the Pope might kneel, peering into the portal of the counter-monument. The oculus he peers into sits centered within the cast gold circle of the counter-monument itself, both entirely hidden by the kneeling body. The prostrate viewer peers into this golden disc (a referent of Canadian extraction processes), embedded at the Venice location of $45^{\circ} 25^{\prime} 40.50^{\prime \prime} \mathrm{N}$ $12^{\circ} 21^{\prime} 30.16^{\prime \prime} \mathrm{E}$ within a white acrylic disc given a topographical relief cut of Bélanger's "Extraction Empire" map. The coordinates inscribed on the gold itself, however, reference the location of the "Contaminated and Abandoned Gold Mine in Furtei, Sardinia (IT)." People are in motion around the prostrated figure and the drawing itself is circularly framed. Bélanger thus formalizes the vertical axis created by the intersection of horizontal axes, not as the outmost point of an orthogonal corner, but as the axial center of a new circle. The formal conception of the grid has provided the landscape architect a new locus and a new virtual form to describe his suggested reorganization of capital by intellectuals in the vein of Tafurian theory.

\section{THE VARIABLE GRID METHOD}

The pace of territorial definition, demarcation, and subsequent exploitative mining by private and public entities has only quickened with the advancements in widespread digital information and technology. The mined environment, wherein time and human metrics are data-mapped alongside spatial data, itself has grown more complex (ripened by capital development practices). Indeed, Bauer and Rose, researchers at the National Energy Technology Laboratory (U.S. Department of Energy) note in their 2015 white paper on the Variable Grid Method (VGM) that "the number of users and disciplines incorporating spatial and spatio-temporal data, and many of their derived products (i.e. maps, figures, graphs, interpolations, analyses, models, etc.) for their research, management, and policy needs" has increased.

The primary concern of Bauer and Rose, given this increased push for credible, data-driven policy, management, and research that relies upon spatial or spatio-temporal data mapping, is that such "data are inherently uncertain." In response to this concern, the VGM was "developed as an intuitive approach that simultaneously communicates both spatial patterns and trends, and the uncertainty associated with data or their analysis." The variable grid in their work is a visualization method that improves the clarity of visual data analysis (by visualizing uncertainties in any spatio-temporal dataset) as well as a design tool that improves the clarity of spatial analysis methodologies, based on this better understanding of relevant uncertainties.

Just as open urban grids at their outermost boundaries represent the front-line of civilization's intent to territorialize the unknown, so do variable grids represent the digital front-lines of that same intent. Bauer and Rose describe VGM: "larger grid sizes denote a larger range of uncertainty," effectively providing various resolutions of data in the same visualization. Most relevant to this discussion of design methodology, though, is the "bottom-up framework" of the mapping itself 

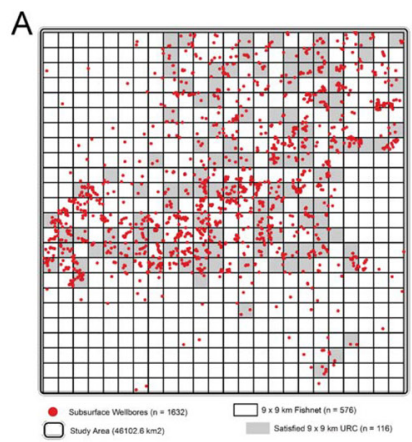

C

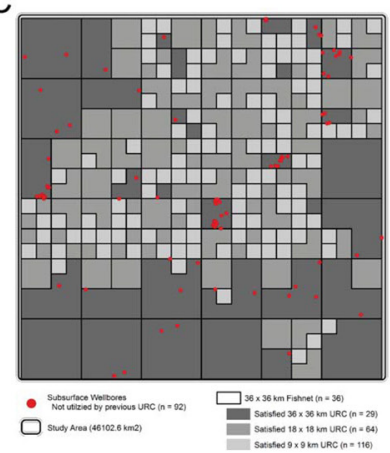

$B$

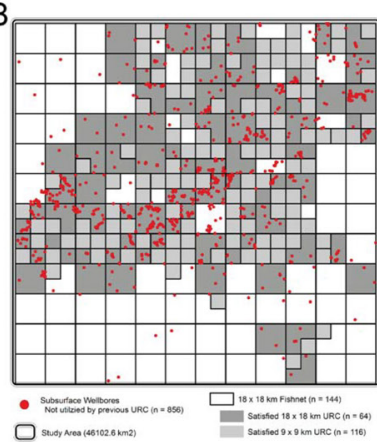

D

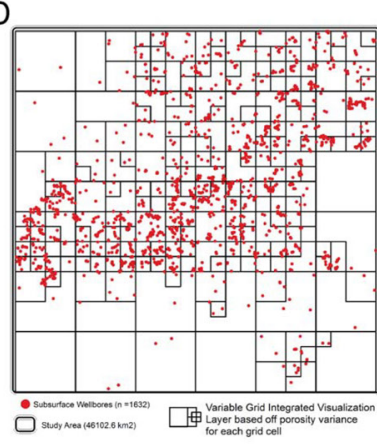

A
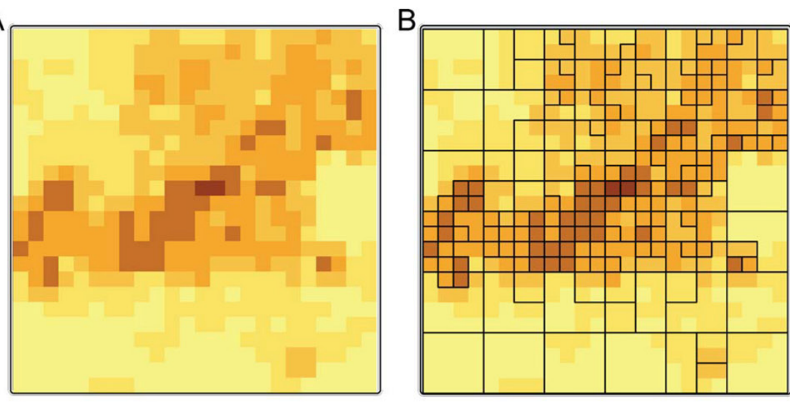

C

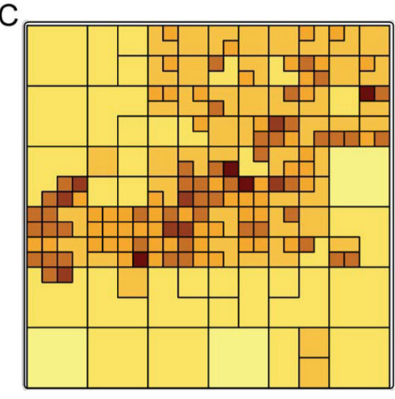

Point Density

per $\mathrm{km} 2$

$0.001 \cdot 0.016$

$0.017 \cdot 0.049$

$0.050 \cdot 0.111$

$0.186 \cdot 0.237$

$0.238 \cdot 0.333$

G Variable Grid Integrated Visualization Layer

Uncertainty
related to number of points per grid cell

田 Grid cells with 6 or more points

$\boxplus$ Grid cells with 3 or more points

Grid cells with 0 or more point
Figure 5. Sample spatial data mapping with VGM (Diagrams by Bauer and Rose, Variable Grid Method, Transactions in GIS 19, no. 3, 2015, 387-388.)

(Figure 5). The grid is not imposed upon a space, as in Brazilian coffee towns, per se. More like Bélanger's siting of the monument in the plaza in relationship to the existing data points of British, French, and Canadian pavilions, the Variable Grid Method computationally generates gridlines and appropriately sized distributions of the grid based upon user input and upon the data itself.

The methods of variable grid analysis - virtualized representations and abstracted aesthetic analyses under the light of a Kraussian reading - are not bound by the same limitations that contort and confine the concrete forms of urban grids. While Bauer and Rose cite the helpful role of VGM in addressing "today's critical issues, such as climate change, energy security, water access, wildlife conservation, risk assessment, human health issues, and others," one might view, through the frame of Bélanger's "Undermining Empire," the profoundly exploitative reach that VGM, an ever-expanding tool set, presents to the agents of capital development.

\section{CONCLUSION}

Over the course of these disparate readings, the Kraussian conceptualization of grids - a design tool of equal force and ambivalence - indicates how such alternative, data-driven, culturally responsive, and ecologically centered grids remain critically relevant to the efforts of ethically engaged design professionals and educators. Grids, vis-à-vis Krauss, provide both material and virtual space for content and meaning, authority and dissent.
From this vantage, Rosaneli's assessment of the use of the grid in the Brazilian frontier stands as both a reinforcement of the Kraussian analysis and a warning. His conclusion that the formal urban grid of frontier coffee towns imposed "a permanent, speculative spirit" even while its use contributed to "distinctive urban centers," outlines the risks inherent to the use of a standardized design method in spatial planning. The Variable Grid Method for visualizing complex and incomplete spatial data, in the further development of such frontier settlements, might be helpful in guiding planners in identifying emergent social trends and the spaces that support them. It might also be wielded by cynical agents of post-colonial enterprise and/or government to further identify and exploit local inhabitants or their environment.

Indeed, the virtualization of geo-spatial grids, as seen in the Variable Grid Method presented by Bauer and Rose, provide designers (as well as private and public entities) a method to describe any given hyper-variable, data-derived spatial domain. It is incumbent upon the current and next generation of designers to understand how such grids are suggested and instrumentalized. These new spaces

provide various opportunities as they must be navigated, surveyed, reorganized, and ethically leveraged and negotiated. Who will site the next virtual intersection, cornerstone, or surveyor's monument? How will they do it, and why? What are the ethical risks and opportunities in relating these new spaces to existing domains, material territories, and/or evolving power structures? 
Following Bélanger's inquiry and critical approach, for example, one can speculate the counter-planning potential of the Variable Grid Method to more accurately map watersheds (and run-off), or to map native and non-native species (or populations) in a way that transcends and undermines the spatial determinism and legacy of the Dominion Land Survey. The alternative spatial knowledge allowed by the Variable Grid Method, here, could be a tool of conservation, restoration, and reparations. In the hands of an ethically driven design professional, planner, or educator, who embraces the seventh point of Bélanger's manifesto (above), the VGM can provide a veritable means of "institutional infiltration" and "systematic unplanning."

The data-driven and hyper-conscious designs, methods, and historical assessments presented by Bélanger, Bauer and Rose, and Rosaneli suggest, in sum, that the grid presents as much an opportunity for the reclamation of social and natural rights as it presents a risk to those very same rights. Architects and other design professionals, then, remain critical operatives in the management of these risks and, more constructively, in the identification of all ethical opportunities to further spatial knowledge and provide meaningful spatial solutions.

\section{ACKNOWLEDGMENTS}

Gratitude to the Connecticut Architecture Foundation for its generous grant.

\section{ENDNOTES}

1 Manfredo Tafuri, "Toward a Critique of Architectural Ideology," trans. Stephen Sartarelli in Architecture Theory since 1968, ed. by Michael K. Hays (Boston: The MIT Press, 1998), 9

2 Rosalind Krauss, “Grids," October 9 (Summer 1979): 50.

3 Krauss, "Grids," 52.

4 Tafuri, "Toward a Critique," 7

5 Tafuri, "Toward a Critique," 6.

6 Krauss, "Grids," 55.

7 Krauss, "Grids," 50.

8 Alessandro Rosaneli, "Grid Plan: New Towns in the Brazilian Coffee Frontier," Journal of Urban Design 19, no. 5 (2014): 638.

9 Rosaneli, "Grid Plan," 638.

10 Rosaneli, “Grid Plan," 640

11 Rosaneli, "Grid Plan," 643.

12 Rosaneli, "Grid Plan," 643.

13 Rosaneli, "Grid Plan," 643.

14 Rosanelli, "Grid Plan," 647

15 Rosaneli, "Grid Plan," 647.

16 Rosaneli, “Grid Plan,” 649

17 Rosaneli, “Grid Plan," 655-57.

18 Pierre Bélanger, Nina-Marie Lister, Christopher Alton and Zannah Matson, Extraction (incl. Undermining Empire, A Landscape Manifesto for the Next Century), Venice, Italy: Venice Biennale 15th International Architecture
Exhibition, 2016. Published in conjunction with an exhibition of the same title, May 28 - November 27, 2016. Catalog Cover.

19 "The Limits of Plan: Pierre Bélanger," Foreground, October 5, 2017, https://www. foreground.com.au/culture/pierre-belanger.

20 Bélanger, Extraction, 36.

21 lbid, 17.

22 Ibid, 138-143.

23 Ibid, 139

24 Ibid, 138-143

25 Tafuri, Manfredo, "Toward a Critique," 9

26 Bélanger, Extraction, 96

27 Ibid, 138

28 Ibid, 95

29 Jennifer Bauer and Kelly Rose, "Variable Grid Method: An Intuitive Approach for Simultaneously Quantifying and Visualizing Spatial Data and Uncertainty." Transactions in GIS 19 (3) (2015): 377, https://doi.org/10.1111/tgis.12158.

30 Bauer and Rose, "Variable Grid Method," 377

31 Ibid, 381

32 lbid, 381

33 Ibid, 377

\section{BIBLIOGRAPHY}

Bauer, Jennifer and Kelly Rose. "Variable Grid Method: An Intuitive Approach for Simultaneously Quantifying and Visualizing Spatial Data and Uncertainty." Transactions in GIS, 19 (3) (2015): 377-397. https://doi.org/10.1111/tgis.12158

Bélanger, Pierre. Extraction (incl. Undermining Empire, A Landscape Manifesto for the Next Century). Venice, Italy: Venice Biennale 15th International Architecture Exhibition, 2016. Published in conjunction with an exhibition of the same title, organized by and presented at the Venice Biennale, May 28 - November 27, 2016.

Bélanger, Pierre. “@1to1Billion: Inside Canada's Contribution to the 2016 Venice Biennale" 29 May 2016. ArchDaily. Accessed 10 Jan 2018. ISSN 0719-8884

Foreground, "The Limits of Plan: Pierre Bélanger," Foreground, October 5, 2017, https://www.foreground.com.au/culture/pierre-belanger.

Krauss, Rosalind. "Grids." October, Vol. 9 (Summer 1979): 50-64. http://www.jstor. org/stable/778321

Rosaneli, Alessandro. "Grid Plan: New Towns in the Brazilian Coffee Frontier." Journa of Urban Design, Vol. 19, no. 5 (2014): 638-659. http://dx.doi.org/10.1080/13574809 .2014 .943702

Tafuri, Manfredo. "Toward a Critique of Architectural Ideology." Translated by Stephen Sartarelli In Architecture Theory since 1968, edited by Michael K. Hays, 1-35. Boston: The MIT Press, 1998. 